\title{
Hyperthermic intrathoracic chemotherapy (HITHOC) should be included in the guidelines for malignant pleural mesothelioma
}

\author{
Marcello Migliore ${ }^{1}$, Michael Ried ${ }^{2}$, Laureano Molins ${ }^{3}$, Marco Lucchi ${ }^{4}$, Marcello Ambrogi ${ }^{4}$, \\ Tamas F. Molnar ${ }^{5}$, Hans-Stefan Hofmann ${ }^{2}$ \\ ${ }^{1}$ Thoracic Surgery, Department of Cardio-thoracic Surgery, University Hospital of Wales, UK and Department of Surgery and Medical Specialties, \\ University of Catania, Catania, Italy; ${ }^{2}$ Department of Thoracic Surgery, University Medical Center Regensburg, Regensburg, Germany; ${ }^{3}$ Department \\ of Thoracic Surgery, Catholic University of Barcelona, Barcelona, Spain; ${ }^{4}$ Thoracic Surgery, University of Pisa, Pisa, Italy; ${ }^{5}$ Thoracic Surgery, \\ Department of Operational Medicine, Faculty of Medicine, University of Pécs, Pécs, Hungary \\ Correspondence to: Marcello Migliore, MD, PhD. Thoracic Surgery, Department of Cardio-thoracic Surgery, University Hospital of Wales, Cardiff, UK. \\ Email: mmiglior@hotmail.com.
}

Submitted Nov 02, 2020. Accepted for publication Dec 17, 2020.

doi: $10.21037 /$ atm-20-7247

View this article at: http://dx.doi.org/10.21037/atm-20-7247

While reading the last guidelines of the task force of the ERS/EACTS/ESTS/ESCRO on treatment of malignant pleural mesothelioma (MPM) (1) we noted that hyperthermic intrathoracic chemotherapy (HITHOC) as adjunct to surgery in MPM has not been even discussed or cited. Being curious about what the other guidelines suggest we read also the guidelines published by other Societies (2-4), and surprisingly even those guidelines do not report about the use of HITHOC as adjuvant treatment. However, although not clearly reported, the ASCO guidelines (3) cite at least 3 papers reporting experience on HITHOC for MPM that have been included in the references list (ref. 61, 118, 171 of the ASCO guidelines 2018).

To prolong survival, one of primary aims in mesothelioma surgical treatment is to improve the local tumor control within a multimodality treatment protocol after surgery such as lung-sparing extended pleurectomy/decortication (P/D) (3-5). Since P/D, known often as surgical cytoreduction, is not expected to achieve an R0 resection, multimodality therapy should always be administered after surgery, and HITHOC is just another type of adjuvant local treatment but performed in the operating room immediately after surgery. Therefore, to improve local tumour control additional local therapy could be useful, and for which reason the effects of intracavitary chemotherapy are now under investigations since the last years (6).

HITHOC is a high concentrated dose of chemotherapy (usually cisplatin) infused in 3-4 liters of normal saline solution (according to the chest size), warmed at $38-43^{\circ}$, introduced and circulated in the chest for 60 minutes after the surgical pleurectomy/decortication, but also after extrapleural pneumonectomy (7-13) (Table 1). The HITHOC acts with a double action: chemotherapeutic drug has a local and direct effect on the tumor cells while hyperthermia enhances the impact of chemotherapy by increasing its penetration into the tissue (13). Furthermore, although many experiences and studies have been reported to date, there is no standardized protocol for HITHOC (14-16).

HITHOC shows promising value after many studies, such as prospective phase I-II trials and robust retrospective series on MPM patients, which have shown good quality of life and prolonged survival up to 35 months median survival without increasing morbidity or mortality (5).

Although guidelines are written after a rigorous systemic review of the literature and based mainly on randomized phase II or III clinical trials, guidelines have demonstrated that most treatments for mesothelioma are "weak", and therefore it sounds unclear why the results of systematic review and metanalysis $(6,17)$ and the published data obtained with surgery and HITHOC as shown in evidence Table 1, should not be included or at least cited in the guidelines. Moreover, the absence of HITHOC in the guidelines could create confusion to our patients as they could erroneously think that the procedure is still experimental, while the reality says that HITHOC is at 
Table 1 Evidence table showing results of surgical procedures associated with HITHOC for malignant pleural mesothelioma

\begin{tabular}{|c|c|c|c|c|}
\hline $\begin{array}{l}\text { Author, year of } \\
\text { publication }\end{array}$ & $\begin{array}{l}\text { Surgical procedure } \\
\text { associated } \\
\text { with HITHOC }\end{array}$ & $\begin{array}{l}\text { No. } \\
\text { pts. }\end{array}$ & $\begin{array}{l}\text { Survival median/ } \\
\text { mean - months }\end{array}$ & Clinical message \\
\hline $\begin{array}{l}\text { Sugarbaker } \\
\text { et al. } 2013\end{array}$ & $\begin{array}{l}\text { EPP } 74 \% \text {; } \\
\text { pleurectomy } \\
\text { decortication } 26 \%\end{array}$ & 72 & $\begin{array}{l}\text { Overall survival } \\
35.3 \text { vs. } \\
22.8 \text { months }\end{array}$ & $\begin{array}{l}\text { A favorable outcome and minimal incremental morbidity support } \\
\text { the incorporation of hyperthermic intraoperative cisplatin } \\
\text { chemotherapy into multimodality treatment strategies for } \\
\text { patients with low-risk epithelial malignant pleural mesothelioma }\end{array}$ \\
\hline $\begin{array}{l}\text { Ried } \\
\text { et al. } 2013\end{array}$ & $\begin{array}{l}\text { Pleurectomy/ } \\
\text { decortication }\end{array}$ & 8 & $\begin{array}{l}\text { Median survival } \\
18 \text { months }\end{array}$ & $\begin{array}{l}\text { Early clinical results may encourage the use of this surgical } \\
\text { option to provide better local tumour control in a multimodality } \\
\text { treatment setting }\end{array}$ \\
\hline $\begin{array}{l}\text { Migliore } \\
\text { et al. } \\
2015-2020^{\circ}\end{array}$ & $\begin{array}{l}\text { VATS pleurectomy } \\
\text { decortication }\end{array}$ & 19 & $\begin{array}{l}\text { Median survival } \\
27 \text { months }\end{array}$ & $\begin{array}{l}\text { Pleurectomy/decortication and HITHOC are a good therapeutic } \\
\text { option in the multimodality treatment of MPM. A randomized } \\
\text { controlled trial is necessary }\end{array}$ \\
\hline $\begin{array}{l}\text { Ambrogi } \\
\text { et al. } 2018\end{array}$ & $\begin{array}{l}\text { Lung-diaphragm- } \\
\text { pericardium-sparing } \\
\text { pleurectomy }\end{array}$ & 49 & $\begin{array}{l}\text { Median survival } \\
22 \text { months }\end{array}$ & $\begin{array}{l}\text { Feasible and safe, with no mortality and low morbidity. } \\
\text { Preserving lung and diaphragmatic function might warrant an } \\
\text { acceptable long-term outcome }\end{array}$ \\
\hline $\begin{array}{l}\text { Klotz } \\
\text { et al. } 2019\end{array}$ & $\begin{array}{l}\text { Pleurectomy } \\
\text { decortication }\end{array}$ & 61 & $\begin{array}{l}\text { Median survival } 42.2 \text { months } \\
\text { in the P/D group vs. } \\
22.4 \text { months for EPP alone }\end{array}$ & $\begin{array}{l}\text { P/D and HITHOC appears safe in mesothelioma patients with } \\
\text { increased overall survival compared to EPP within a trimodal } \\
\text { treatment approach }\end{array}$ \\
\hline
\end{tabular}

${ }^{\circ}$, in the present manuscript the number of operated patients in Catania has been updated from 6 in 2015 to 2019. HITHOC, hyperthermic intrathoracic chemotherapy; MPM, malignant pleural mesothelioma.

least 20 years old but it is only less used. Nonetheless, the procedure is still viewed with some suspicion based mainly by discrepancies in the methods and significant toxicities such as acute renal injury that have been only rarely reported by HITHOC (18).

As uncertainty still exists in the treatment of MPM, it is evident that the gold standard treatment remains a moon shot, and for this reason new ideas, and innovations based on a strong scientific background should be always welcomed. Academic centers should take responsibility on a global scale to perform more pilot studies (19), and multicenter large randomized controlled trials (20) to confirm or perform new treatments.

Writers of future guidelines on MPM should therefore be encouraged to discuss and/or include HITHOC as a type of "adjuvant" treatment to be considered after debulking surgery for MPM.

\section{Acknowledgments}

Funding: This study has been funded in part by the University of Catania FIR Research Program 2014-2016 and Department Research Program 2016-2018.

\section{Footnote}

Provenance and Peer Review: This article was commissioned by the editorial office, Annals of Translational Medicine for the series "Hyperthermic Intraoperative Chemotherapy (HITHOC) in thoracic surgical oncology". The article did not undergo external peer review.

Conflicts of Interest: All authors have completed the ICMJE uniform disclosure form (available at http://dx.doi. org/10.21037/atm-20-7247). The series "Hyperthermic Intraoperative Chemotherapy (HITHOC) in thoracic surgical oncology" was commissioned by the editorial office without any funding or sponsorship. MM served as the unpaid Guest Editor of the series and serves as an unpaid editorial board member of Annals of Translational Medicine 
from Dec 2018 to Nov 2020. The other authors have no conflicts of interests to declare.

Ethical Statement: The authors are accountable for all aspects of the work in ensuring that questions related to the accuracy or integrity of any part of the work are appropriately investigated and resolved.

Open Access Statement: This is an Open Access article distributed in accordance with the Creative Commons Attribution-NonCommercial-NoDerivs 4.0 International License (CC BY-NC-ND 4.0), which permits the noncommercial replication and distribution of the article with the strict proviso that no changes or edits are made and the original work is properly cited (including links to both the formal publication through the relevant DOI and the license). See: https://creativecommons.org/licenses/by-nc-nd/4.0/.

\section{References}

1. Scherpereel A, Opitz I, Berghmans T, et al. ERS/ ESTS/EACTS/ESTRO guidelines for the management of malignant pleural mesotelioma. Eur Respir J 2020;55:1900953.

2. Ettinger DS, Wood DE, Akerley W, et al. NCCN Guidelines Insights: Malignant Pleural Mesothelioma, Version 3.2016. J Natl Compr Canc Netw 2016;14:825-36.

3. Kindler HL, Ismaila N, Armato SG 3rd, et al. Treatment of Malignant Pleural Mesothelioma: American Society of Clinical Oncology Clinical Practice Guideline. J Clin Oncol 2018;36:1343-73.

4. Woolhouse I, Bishop L, Darlison L, et al. BTS guideline for the investigation and management of malignant pleural mesothelioma. BMJ Open Resp Res 2018;5:e000266.

5. Sugarbaker DJ, Gill RR, Yeap BY, et al. Hyperthermic intraoperative pleural cisplatin chemotherapy extends interval to recurrence and survival among low-risk patients with malignant pleural mesothelioma undergoing surgical macroscopic complete resection. J Thorac Cardiovasc Surg 2013;145:955-63.

6. Zhao ZY, Zhao SS, Ren M, et al. Effect of hyperthermic intrathoracic chemotherapy on the malignant pleural mesothelioma: a systematic review and meta-analysis. Oncotarget 2017;8:100640.

7. Opitz I, Lauk $O$, Meerang $M$, et al. Intracavitary cisplatinfibrin chemotherapy after surgery for malignant pleural mesothelioma: A phase I trial. J Thorac Cardiovasc Surg 2019. doi: http://dx.doi.org/10.1016/j.jtcvs.2019.07.073.

8. Tilleman TR, Richards WG, Zellos L, et al. Extrapleural pneumonectomy followed by intracavitary intraoperative hyperthermic cisplatin with pharmacologic cytoprotection for treatment of malignant pleural mesothelioma: A phase II prospective study. J Thorac Cardiovasc Surg 2009;138:405-11.

9. Ried M, Potzger T, Braune N, et al. Cytoreductive surgery and hyperthermic intrathoracic chemotherapy perfusion for malignant pleural tumours: Perioperative management and clinical experience. Eur J Cardiothorac Surg 2013;43:801-7.

10. de Bree E, van Ruth S, Baas P, et al. Cytoreductive surgery and intraoperative hyperthermic intrathoracic chemotherapy in patients with malignant pleural mesothelioma or pleural metastases of thymoma. Chest 2002;121:480-7.

11. Burt BM, Richards WG, Lee HS, et al. A Phase I Trial of Surgical Resection and Intraoperative Hyperthermic Cisplatin and Gemcitabine for Pleural Mesothelioma. J Thorac Oncol 2018;13:1400-9.

12. Ambrogi MC, Bertoglio P, Aprile V, et al. Diaphragm and lung-preserving surgery with hyperthermic chemotherapy for malignant pleural mesothelioma: A 10-year experience. J Thorac Cardiovasc Surg 2018;155:1857-66.e2.

13. Ried M, Lehle K, Neu R, et al. Assessment of cisplatin concentration and depth of penetration in human lung tissue after hyperthermic exposure. Eur J Cardiothorac Surg 2015;47:563-6.

14. Migliore M, Calvo D, Criscione A, et al. Pleurectomy/ decortication and hyperthermic intrapleural chemotherapy for malignant pleural mesothelioma: initial experience. Future Oncol 2015;11:19-22.

15. Klotz LV, Grünewald C, Bulut EL, et al. Cytoreductive surgery and hyperthermic intrathoracic chemoperfusion shows superior overall survival compared to extrapleural pneumonectomy for pleural mesothelioma. Zentralblatt für Chirurgie 2019;144:V137.

16. Markowiak T, Koller M, Zeman F, et al. Protocol of a retrospective, multicentre observational study on hyperthermic intrathoracic chemotherapy in Germany. BMJ Open 2020;10:e41511.

17. Zhou H, Wu W, Tang X, et al. Effect of hyperthermic intrathoracic chemotherapy (HITHOC) on the malignant pleural effusion: A systematic review and meta-analysis. Medicine (Baltimore) 2017;96:e5532.

18. Markowiak T, Kerner N, Neu R, et al. Adequate nephroprotection reduces renal complications after hyperthermic intrathoracic chemotherapy. J Surg Oncol 2019;120:1220-6. 
19. Migliore M, Nardini M, Meli A, et al. Comparison of VATS debulking surgery and HITHOC vs VATS talc pleurodesis alone in malignant pleural mesothelioma: a

Cite this article as: Migliore M, Ried M, Molins L, Lucchi M, Ambrogi M, Molnar TF, Hofmann HS. Hyperthermic intrathoracic chemotherapy (HITHOC) should be included in the guidelines for malignant pleural mesothelioma. Ann Transl Med 2021;9(11):960. doi: 10.21037/ atm-20-7247 pilot study. Eur Resp J 2020;56:4489.

20. Migliore M. Malignant pleural mesothelioma: between pragmatism and hope. Ann Transl Med 2020;8:896. 